\title{
THE ORGANIZATION OF PASSENGER TRANSPORTATIONS BY INTRA-REGIONAL BUS ROUTES OF COMMON USE AT THE PRESENT STAGE
}

\begin{abstract}
A.B. Вітковський. Організація пасажирських перевезень внутрішньообласними автобусними маршрутами загального користування на сучасному етапі. Сучасна криза міського пасажирського транспорту в цілому у світі і в Україні зокрема викликана, насамперед, неконтрольованою автомобілізацією, що погіршує пропускну здатність міської транспортної мережі. Крім неконтрольованої автомобілізації особливої уваги потребує питання недосконалості нормативно-правової бази, регулюючої пасажирські перевезення, що насамперед стосується країн колишнього соціалістичного блоку. Мета: Метою дослідження є аналіз сучасного стану організації пасажирських перевезень маршрутами загального користування і недоліків існуючої законодавчої бази, що має забезпечувати ефективну й безпечну роботу міського пасажирського транспорту, а також визначення шляхів розв'язання проблем транспортної системи міста. Матеріали і методи: Проведено аналіз недоліків існуючої законодавчої бази з організації роботи міського пасажирського транспорту. Аналіз проводився на базі транспортної системи м. Одеси. Показано, що основними проблемами, які негативно впливають на реалізацію чинних законів і нормативних актів, а також на ефективність роботи громадського транспорту міста, $є$ відсутність концепції й комплексного плану розвитку громадського транспорту й автодорожньої інфраструктури в цілому і невиконання організатором перевезень основних вимог до організації транспортного обслуговування населення. Результати: В результаті аналізу сучасного стану організації пасажирських перевезень маршрутами загального користування і недоліків існуючої законодавчої бази визначено шляхи розв'язання проблем транспортної системи міста, а саме: удосконалення галузевої правової бази і методів державного управління автомобільним транспортом і системною організацією дорожнього руху, раціональна взаємодія дорожньо-транспортного комплексу і містобудівного планування, оперативна організація дорожнього будівництва і максимальне збереження існуючої дорожньої мережі тощо. Особливу увагу слід приділити підвищенню відповідальності за порушення законодавства з автомобільного транспорту, поновленню регулярних рейдових перевірок на маршрутній мережі щодо виявлення нелегальних (незаконних) рейсів.

Ключові слова: перевізник, пасажир, нормативно-правова база, транспортне обслуговування.
\end{abstract}

A.V. Witkowski. The organization of passenger transportations by intra-regional bus routes of common use at the present stage. The current crisis of public passenger transport in the world and in Ukraine in particular, caused primarily by uncontrolled motorization that impairs the capacity of city transport network. In addition to uncontrolled motorization a question of imperfection of the legal framework, regulating passenger services (which primarily concerns the former socialist bloc) needs a special attention. Aim: The aim of the study is to analyze the current state of passenger transportation by routes of general use and shortcomings of the existing legislative framework which should ensure efficient and safe operation of public passenger transport as well as guidance for the solution of the city transport system problems. Materials and Methods: This paper analyzes the shortcomings of the existing legislative framework for the organization of public passenger transport. For the analysis in the article the transport system of Odessa is taken. It is shown that the main problems of implementation of existing laws and regulations that adversely affect to the efficiency of the city public transport are the lack of the concept and a comprehensive plan of public transport and road infrastructure in general, and unfulfilment by transportation organizers the key requirements for improving of transport services. Results: In the analysis of the current state of passenger transportation routes of general use and disadvantages of the existing legislative framework the ways to solve problems of the transport system of the city have been pointing, namely: improving of branch legislation framework and methods of state administration for motor transport system traffic organization; rational interaction between road transport sector and urban planning; operational organization of road construction and maximum preservation of the existing road network, and more. Particular attention should be paid to increasing of responsibility for violations of legislation on road transport, the resumption of regular checks on route network to detect illegal routs.

Keywords: carrier, passenger, regulatory framework, transport service.

Introduction. The current crisis of public passenger transport in the world and in Ukraine in particular primary caused by uncontrolled motorization that impairs the capacity of transport city network.

Today 600 cars per 1000 residents is quite normal for the average in European country. The level of $250 \ldots 300$ cars in most European countries was reached in $1960 \ldots 1970$ of twentieth century, and in the US in the first half of the twentieth century.

Thus, according to NationMaster.com [1] in 2014 on motorization the top in the world occupied by San Marino with the index 1263 cars per 1000 residents, the second - Monaco with 899, and the third - US with 797. 
In addition to the uncontrolled motorization a special attention requires a question of imperfection of the legal framework that regulates passenger services, which primarily relates to the former socialist bloc.

The main problems of the transport system can be systematized and divided into objective and subjective.

The objective problems include:

- uncontrolled growth of motorization of the population and, consequently, increased intensity of use of individual vehicles;

- decrease in efficiency of public passenger transport;

- growth needs of residents to move;

- discrepancy between the level of motorization and pace of road construction;

- urban problems of the city.

Subjective problems include:

- imperfection of the legislative framework at the local level in the management of transport system of the city;

- insufficient system of organization and management of the development of road transport sector;

- insufficient financing of road-transport infrastructure;

- negative impact of the human factor.

To increase the efficiency of the existing transport system should take in to account objective problems, but special attention should be given to subjective issues in general and the legal framework in particular.

There are many scientific works devoted to the improvement of transport services. Among them, the work of such scientists as V.R. Vuchic [2], D.-H. Lee [3], G. Jönson and E. Tengström [4], V. Gromule and I. Yatskiv [5], M. Attard and Y. Shiftan [6], etc.

For the carrier, who must provide reliable, safe and comfortable transportation of passengers and to ensure the effective functioning of the transport system of the city, one of the main problems is the inadequacy of existing laws and regulations.

The aim of the study is to analyze the current state of passenger transportation by routes of general use and shortcomings of the existing legislative framework which should ensure efficient and safe operation of public passenger transport as well as guidance for the solution of the city transport system problems.

Materials and Methods. For the analysis in this paper is taken of the transport system of Odessa, but the conclusions and recommendations can be adapted to other major cities in Ukraine. Currently, one of the key problems of the transport system for Ukraine in general and for the Odessa are in particular the regulatory framework which has to enforce the transport policy of large cities taking into account their specific features.

Legislative acts have many shortcomings and omissions. There are also no clear and comprehensive delimitation between the state and local levels of government.

Factors that depend on the regulatory framework and affect the efficiency of the transport system of the city are shown in Fig. 1.

It is clear that the current laws and regulations need to perform all participants in the transport process, transport organizers, carriers, passengers and supervisory authorities (Transport Safety Authorities, Police).

Fig. 2 shows the problems of implementation of existing laws and regulations that affect the efficiency of the public transportation of Odessa. Let us consider the following problems.

The first problem - the lack of the concept and a comprehensive plan for public transportation (taxi, bus, electric) and road infrastructure as a whole. The growing number of individual transport, lack of quality roads and road junctions in Odessa, the problem is exacerbated with each passing year. It is, accordingly, affects the quality of service and traffic safety population. 


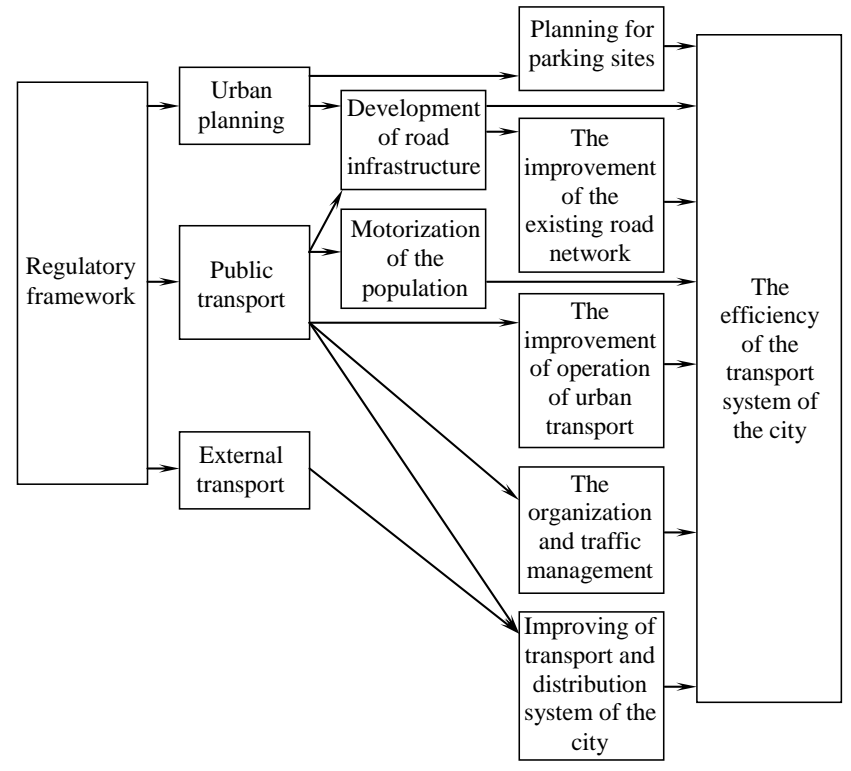

Fig. 1. Factors of regulatory framework affecting the efficiency of the transport system of the city

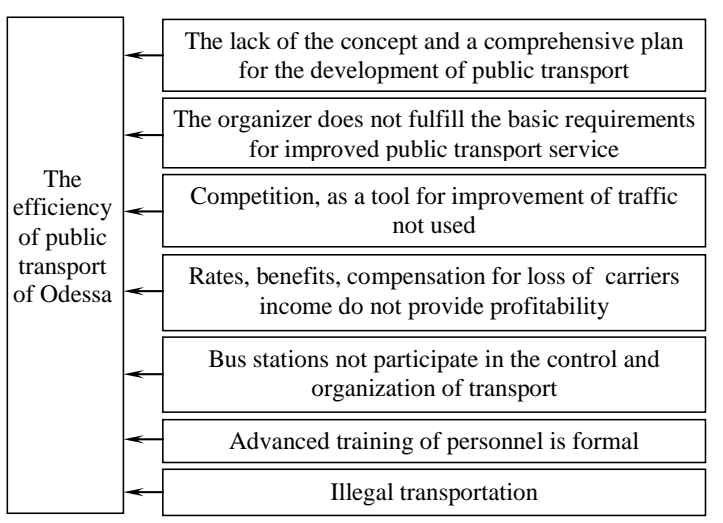

Fig. 2. The main problems of public transport in Odessa

The second problem - organizer does not fulfill the basic requirements for public transport services improving, i.e.:

- not developed an optimal route network with all modes of transport;

- not solved the problem of transport service of the population in the city and suburban routes (introduction taxi yielded no significant results; route network was formed by carriers and continues to be served by remodeled "minibuses");

- the requirement for obligatory route bus fleet structure is not the competition;

- did not provide conditions for job growth and business profitability of the carrier;

- no traffic organization of public transport in order to provide certain advantages over other members of the movement.

One of the effective tools for improving the organization of transport is a competition which is currently not used, that is:

- formal competitions are held;

- the interests of passengers in terms of competition is not considered, that virtually no standards of social security of the population in transport services and quality services;

- competitions are not considered the tariffs, traffic intervals and bus schedules;

- no competition of investment projects. The economic, tax, social conditions of business operation do not create for them;

- carriers use different forms of business organizations which are taxed at different rates. That is leading to unfair competition between private firms, small and large enterprises (competitive conditions give preference to large enterprises).

Another important issue is that the rates, benefits, compensation for loss of income of carriers do not provide profitability of the business, namely:

- tariffs and benefits ensure profitability of $10 \%$ (the desired return of $15 \%$ ), which does not allow the renewal of the rolling stock and the quality of services;

- payment ability of passengers does not ensure profitable activity of carriers in terms of European price of rolling stock, fuel, oil. It should be understood that the passengers as consumers of transport services, want a comfortable and safe transport with low fares. Meanwhile, the price for travel anytime and anywhere directly related to the cost of gasoline (for Ukraine the price liter of 
gasoline reaches 1...1.2 USD). Thus, the price of travel in the $20 . . .25$ cents will always be a way for carrier and authorities to justify the inability to provide quality and safe passenger transport services

- regulated tariffs for passenger on suburban and urban routes and compensation for their use in law are not defined;

- the introduction of electronic tickets in law not approved.

Autostations do not participate in the control and organization of traffic on suburban and longdistance routes. According to Article 44 of the Law of Ukraine "On Automobile Transport" organization of the contest and determine the conditions of transportations rely on the executive authorities and local authorities [7].

According to the author, in a contest it is necessary to involve representatives of autostation for more productive work with the carrier in the future in the public service.

Equally important condition for the successful development of the transport business is staff. Staff training at the present time is formal, namely:

- training of drivers providing licensed transportation services is not defined by legislation;

- no system of state order, training, retraining of executives, managers, professionals and skilled workers in licensed educational institutions;

- training of skilled workers in educational institutions of Odessa and Odessa region is not carried out;

- qualification requirements for education specialties do not match the qualification requirements of professions.

The implementation of illegal traffic not improve the situation. Carriers who are engaged in illegal routes of transportation of passengers, providing transportation services with the following violations:

- violation of bus schedules;

- violation of bus speed in the city;

- lack of data on passengers;

- failure to comply with basic safety rules for the carriage of passengers.

Results. To solve these problems the author suggested the following steps.

In the development plan of public transport and active transport system it is necessary to pay attention to the following issues:

- improving sectoral framework and methods of state administration of motor transport and system organization of traffic;

- rational interaction between road transport sector and urban planning;

- operational organization of road construction and maximum preservation of the existing road network.

To improve and streamline the public transport in order to ensure comfortable and safe conditions for direct passengers from one vehicle to another and efficiency of the rolling stock is necessary to optimize the route network with the use of transport logistics principles, namely:

- avoid duplication of routes of public transport;

- reduce transit routes of public transport that pass through the city center;

Allocate public transport routes, taking into account the capacity of roads, permissible speed and according to the passenger traffic on the route;

- Open new public transport routes to meeting the needs of the population.

- To implement new projects: construction of road junctions, the introduction of light rail and bicycle infrastructure, and so on.

It is also necessary to improve the situation within the competition system, thus achieving more effective and higher performance of transport services. To do this:

- to create thoughtful and well-balanced system of competition on the base of objective assessments of the candidates and formation of items that combine low-profit and unprofitable socially important routes with profitable;

- to conclude contracts with carriers for a long period of time (3 to 5 years), which may serve as an incentive for investment in the field of passenger transportation funding and attract new carriers; 
- to provide subsidies for population on transport services in order to compen sate the carrier for losses arising from rate regulation and transportation of privileged categories of citizens.

To meeting the requirements of population for transport services in quantitative, qualitative and economic parameters and to simultaneously ensure profitability of public transport should be used complex measures:

- the use of instruments of regulation of tariff policy;

- increasing population salaries;

- monitoring tariff to limit the impact of inflation;

- limiting tariffs to ensure the availability of transport services and avoid providing services below cost (dumping) or long-term use of depressed prices;

- the introduction of electronic ticket (in the West countries a long time already used similar payment mechanisms and accounting system of passengers, the introduction of an electronic ticket can provide an opportunity to improve service level of the population and will keep records of passengers).

To conduct consultations and promote laying agreements between the owners of bus stations and state administration. To work out proposals for amending existing agreements with Ukrainian Transport Inspection to ensure service provision to residents to obtain information on services before the trip and during it, and joint action to eliminate the illegal traffic of nearby area bus stations.

Also appropriate is the introduction of modern traffic management systems of public transport that will ensure equal access to the information of participants of road traffic.

Given the fact that the object of attention is a motor transport enterprise, it is worth noting a number of specific measures to improve vocational training of workers. These measures could improve the system of training and retraining of personnel of the enterprise and the enterprise work as a whole. In particular, it is useful to the following:

- review the content of training programs for compliance of their contents with needs of the workplace for drivers, maintenance personnel, managers, administrative personnel;

- make a gradual transition to active learning methods (training, programmed instruction, group discussions, business and role-playing games); thus, together with the active mastering by educational institutions of new forms of the educational process (design of work situations, organizing discussions);

- prepare educational videos and presentations;

- increase the number of seminars for executives and specialists of the course "Ethics and psychology of behavior". In general, for these categories of workers in the learning process will useful the block economics and management.

To achieve this goal it is necessary to apply network expansion of intra regional routes of public use, offering illegal licensed carriers on the competitive conditions of carriages to the settlements that not provided with bus service, on routes that are currently not working as well as new regular flights (routes) that they are now serving illegally.

The output from the shadows of illegal carriers - an important step to improve the transport situation. It should provide all possible assistance and support to illegal carriers that would like to operate in the legal field.

Particular attention should be paid to increasing accountability for violations of legislation on road transport, the resumption of regular checks on route network to detect illegal (illegal) flights. Also it is necessary take the political decision to eliminate illegal traffic and to establish personal responsibility of officials from regulatory authorities, which are responsible for the failure of regular passenger transportation.

It makes sense to maximize distribute information and communicate to the passenger in the public bus, at the bus station and in the media about the risks that may occur while using illegal services.

To stop illegal traffic on the public use regional routes necessary to provide adequate level of regular transportation services for which every month should be monitored, firstly, the population's needs in passenger traffic, and secondly, violations of transport legislation and refuse to residents in transportation in reason of the lack of scheduled flights or available seats in the buses. 
Conclusions. This paper analyzes the impact of imperfections in the existing laws and regulations to ensure efficient and safe operation of public passenger transport of Odessa.

There are ways for possible activities of the transport traffic organizers, regulatory authorities, together with the legal carriers, autostation and public organizations that are required to effectively solve the problems of the transport system of the city of Odessa.

\section{Література}

1. Motor vehicles per 1000 people: Countries Compared [Електронний pecypc] / NationMaster. Режим доступу: http://www.nationmaster.com/country-info/stats/Transport/Road/Motor-vehicles-per1000-people (Дата звернення: 11.08.2016).

2. Vuchic, V.R. Urban transit systems and technology / V.R. Vuchic. - Hoboken: John Wiley \& Sons, 2007. $-602 \mathrm{p}$.

3. Urban and regional transportation modeling: essays in honor of David Boyce / ed. by D.-H. Lee. Cheltenham: Elgar, 2004. - 398 p.

4. Jönson, G. Urban transport development: a complex issue / G. Jönson, E. Tengström. — Berlin: Springer, $2005 .-301 \mathrm{p}$.

5. Gromule, V. Coach terminal as important element of transport infrastructure / V. Gromule, I. Yatskiv // Transport. - 2007. - Vol. 22, Issue 3. - PP. $200-206$.

6. Attard, M. Sustainable urban transport / M. Attard, Y. Shiftan. - Bingley: Emerald, 2015. - 271 p.

7. Про автомобільний транспорт: закон України від 05.04.2001 № 2344-III, редакція від 28.12.2015 // Відомості Верховної Ради України. - 2016. — № 4. - С. 44.

\section{References}

1. NationMaster. (n.d.). Motor vehicles per 1000 people: Countries compared. Retrieved from http://www.nationmaster.com/country-info/stats/Transport/Road/Motor-vehicles-per-1000-people

2. Vuchic, V.R. (2007). Urban Transit Systems and Technology. Hoboken: John Wiley \& Sons.

3. Lee, D.H. (Ed.) (2004). Urban and Regional Transportation Modeling: Essays in Honor of David Boyce. Cheltenham: Elgar.

4. Jönson, G., \& Tengström, E. (2005). Urban Transport Development: A Complex Issue. Berlin: Springer.

5. Gromule, V., \& Yatskiv, I. (2007). Coach terminal as important element of transport infrastructure. Transport, 22(3), 200-206.

6. Attard, M., \& Shiftan, Y. (2015). Sustainable Urban Transport. Bingley: Emerald.

7. Law of Ukraine "On Automobile Transport" (Vidomosti Verkhovnoi Rady Ukrainy, 2016, No. 4, p. 44).

Received September 10, 2016

Accepted October 15, 2016 